co-ordination is not to overlay new lines of research and criticism of the old lines. The constitution of the Council for the Social Sciences which the British Association Committee envisaged was thought out precisely to avoid the 'representatives' of existing institutions of one type overlaying any promising baby. In particular, new social sciences should be growing up and pioneering in the marginal ground between recognized orthodox disciplines such as economics and political science and also in the wide desert (or is it a jungle ?) between the natural and the social sciences.

An argument that the Clapham Committee might have, but did not, use to appeal to the more hard. headed natural scientists is that social sciences, such as social biology and industrial psychology, assume the same material basis of human inheritance as the biological natural sciences, and indeed that there is no hard and fast line dividing natural from social phenomena. As the British Association Committee pointed out, the line at present drawn by the Royal Society in its admission to fellowship splits anthropology and psychology into two. Physical anthropologists and experimental psychologists have been recognized as scientists, but not their social colleagues. Such a dichotomy may not be as unworkable as the Potsdam zoning, but it is scarcely 'natural'. The natural sciences not only grade, without natural frontier, into the social sciences, but through their technical applications impinge on society and profoundly change the practical problems to be studied by social science. The atom bomb has straightway given political science the pretty but urgent problem of the 50 per cent vote, the 66 per cent vote, the veto, etc., in deciding United Nations policy. This impact was recognized in the founding of the British Associa. tion Division on the Social and International Rela. tions of Science; and it must be recognized in all future organisation and financing of the social sciences.

Accordingly, for the purpose of achieving a coordination of social and natural sciences (together with criticism, but not restriction, of pioneer work, for example, by vested interests), the British Association Committee suggested a Council to disburse research funds, to advise the Government and to co-ordinate, which would mix representatives of existing (and possibly vested) interests such as university departments and research-endowing institutes, with members less likely to be chosen as 'regular guys' (for example, by the social science sections of the British Association); and which would mix social with natural scientists chosen, for example, by the Royal Society.

Admittedly this is a long-term programme against the day when there are more social scientists. Until then it is probably wiser to have no co-ordinating body than a possibly restrictive body, and the Clapham Committee's proposal to leave the financing of social research at the university to the existing University Grants Committee may be welcome, even though its membership is rather short on the social science side. It is now up to the universities to put forward plans adequate to the additional funds likely to be offered them. The Clapham Committee has given them a sympathetic consideration, and a wise lead.

1 Privy Council Office: Treasury. Report of the Committee on the Provision for Social and Economic Research. (Cmd. 6868.) Pp. 16. (London: H.M. Stationery Office, 1946.) 3d. net.

a Committee's Report on Scientific Research on Human Institutions, The Advancement of Science, Aug. 1943 (British Association) Nature, 152, 669 (1943).

\section{OBITUARIES}

Dr. Otto May

Dr. Oтto May, whose unexpected death took place on August 15, was Girman of the British Social Hygienenlsuncil ond, before his retirement, principal meglat gen of the Prudential Assurance

Fysreer was varied and distinguished. He took a fi I in both parts of the Natural Sciences Tripos at Cambridge. Later, at University College Hospital, London, he won the Atchison Scholarship, the Lisbon Medal, a Beit Research Fellowship and the British Medical Association Research Scholarship. $\mathrm{He}$ also worked at the University College Hospital, Great Ormond Street Children's Hospital, the West End Hospital for Nervous Diseases, and the Evelina Hospital for Children.

Dr. May's association with the Council dates from its earliest days, and he became joint honorary secretary of the National Council for Combating Venereal Diseases in December 1914. He lectured indefatigably on venereal disease to the troops during the First World War. It was largely due to his efforts that insured patients suffering from venereal disease received sickness benefits, from which they had previously been debarred. His work for merchant seamen was notable: he attended the meeting of the International Labour Office of the League of Nations at Geneva in 1920, which resulted in the Brussels Agreement in 1924. This was followed by the Seamen's Welfare in Ports Recommendations in 1933, and finally the Ministry of Labour set up a special Departmental Committee on Port Welfare at the beginning of the Second World War.

In 1925 the National Council for Combating Venereal Diseases changed its name to the British Social Hygiene Council, and in 1938 Dr. May became chairman of the Executive Committee-a position he held until his death. His great gifts were used unsparingly on behalf of the work of the Council; in committee he was able to grasp the outstanding points raised and to place them in their right perspective; exaggeration and muddled thinking were always anathema to him. His balanced judgment and wise counsel will be sadly missed.

One of the last pieces of work he undertook was to write a brief history of the Council which he served so faithfully. ELEANOR FRENCH

\title{
Prof. E. C. Bingham
}

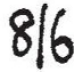

No. 1, volume 17, Ahe Rheology Bulletin (May 1946) bears the tis of "E. C. Bingham Memorial Edition", and pmains tributes to the memory of Prof. Eugeng Cook Bingham from the American Institute of Physics, the American Chemical Society, the American Society of Testing Materials, the National Bureau of Standards, and Lafayette College, Easton, Pennsylvania, at which he held the chair of chemistry for the past twenty-nine years. Prof. Bingham graduated from Middleburg College, Vermont, and the Johns Hopkins University. He was. professor of chemistry at Richmond College, Virginia, from 1906 to 1915 ; then, for a time during World War I, an assistant physicist at the National Bureau of Standards, where his work led to an outstanding paper entitled "An Investigation of the Laws of Plastic Flow". In 1916 he was appointed to the 